УДК 378.014.25:303.424]:001.4(045)

ІРИНА ЩЕРБАК, кандидат педагогічних наук, викладач кафедри інформатики, Комунальний заклад "Харківська гуманітарно-педагогічна академія" Харківської обласної ради, Україна ORCID 0000-0003-4161-735X

\title{
ВИКОРИСТАННЯ КАРТ-ПЕРЦЕПЦІЙ В АНАЛІЗІ СТРАТЕГІЙ ПОЗИЦІОНУВАННЯ ПРОВІДНИХ УНІВЕРСИТЕТІВ КРАЇН ЗАХІДНОӤ ЄВРОПИ В МІЖНАРОДНОМУ ІНФОРМАЦІЙНОМУ ПРОСТОРІ
}

\author{
IRYNA SHCHERBAK, PhD of Pedagogical Sciences, lecturer \\ at the Department of Informatics Municipal Establishment \\ "Kharkiv Humanitarian-Pedagogical Academy" of \\ Kharkiv Regional Council, Ukraine
}

\section{THE USE OF PERCEPTION MAPS IN THE ANALYSIS OF POSITIONING STRATEGIES OF LEADING UNIVERSITIES IN WESTERN EUROPE IN THE INTERNATIONAL INFORMATION SPACE}

\begin{abstract}
У статті проаналізовано ефективність використання карт-перцепцій на основі наукових досліджень. Розглянуто їх застосування в аналізі стратегій позиціонування провідних університетів країн Західної Свропи в міжнародному інформаційному просторі, зокрема, на прикладі провідних університетів Бельгії (Левенський католицький університет, Гентський університет, Лувенский католицький університет, Брюссельський університет (ULB), Вільний університет Брюсселю (VUB)). Розроблено алгоритм проведення порівняльно-педагогічного аналізу стратегій позиціонування провідних університетів країн Європи в міжнародному інформаційному просторі.

Ключові слова: карти-перцепції, стратегічні карти, провідний університет.

Summary. The article analyzes the effectiveness of using perception maps based on scientific research. The use of perception maps in the analysis of positioning strategies of leading universities in Western Europe in the international information space, in particular, with the example of leading
\end{abstract}

(ㄱ) I. Щербак universities in Belgium (Leuven Catholic University, Ghent University, Louvain Catholic University, Brussels University (ULB), Free University of Brussels (VUB)). An algorithm has been developed for conducting a comparative pedagogical analysis of positioning strategies of leading universities in Europe in the international information space.

Key words: perception maps, strategic maps, leading university.

Мета: оглянути ефективність використання карт-перцепцій в аналізі стратегій позиціонування провідних університетів країн Західної Європи в міжнародному інформаційному просторі.

Постановка проблеми в загальному вигляді. На сучасному етапі стрімкого розвитку освіти одним 3 головних факторів $\epsilon$ стійка позиція на ринку освітніх послуг серед закладів вищої освіти. Але щоб утриматися на вищому рівні, потрібно розуміти та вміти визначити сильні і слабкі сторони, можливості інших ЗВО. Саме для встановлення таких даних прибігають до карт-перцепцій.

Карта-перцепція (карта сприйняття) - це часто використовувана частина аналізу, яка допомагає зрозуміти становище підприємства або ЗВО стосовно їх основ- них конкурентів. Карти-перцепції застосовують роздрібні фірми для виявлення прогалин у регіоні, де може бути відкритий новий магазин, або фірми-виробники споживчих товарів, щоб дослідити ефективність запуску нового продукту.

Типова карта сприйняття може відображати асортимент товарів 3 урахуванням двох чинників, тому виробник шоколаду має змогу порівнювати ціну з якістю.

Для університетів існує безліч змінних. Ключовими питаннями повинні бути: чим мій навчальний заклад відрізняється від конкурентів? як я можу використовувати цю відмінність, щоб стати більш успішним? чи будуть нинішні студенти та абітурієнти, які відмовились від навчання у вашому закладі, відрізнятися?

Аналіз досліджень і публікацій. Теорією позиціонування підприємств займалися Д. Аакер, О. Зозулєв, Ф. Котлер та інші. У своїх працях Д. Ільницький, А. Лялюк, Р. Патора, Я. Стоказ, Н. Чухрай при вивченні концепції стратегій позиціонування організацій використовували "стратегічні карти" та "карти-перцепції".

Виклад основного матеріалу дослідження. Проаналізуємо науково-педагогічну літературу 
щодо питання ефективного використання стратегічних карт та карт-перцепцій в аналізі стратегій позиціонування провідних університетів країн Західної Європи в міжнародному інформаційному просторі.

У своїй дисертаційній роботі "Формування стратегічних знань промислового підприємства" Я. Стоказ вважає, що стратегічні карти - це спосіб узгодження цілей діяльності й контролю за їхнім досягненням. Основна ідея стратегічних карт полягає в тому, що використовувані в управлінському контролі показники дуже різноманітні, і необхідно їх узгодити не тільки з фінансовими цілями, але й між собою як за змістом, так і термінами реалізації (Стоказ, 2009, с. 44).

На думку Д. Ільницького, застосування якісних показників, що характеризують науковоосвітній простір країн у їх взаємозв'язку з ВВП та ВВП на особу, для аналізу науково-освітніх ринків може бути інтегроване у традиційну методику побудови конкурентних карт ринку. Аналіз конкурентних карт глобального науково-освітнього простору як проміжного середовища підтвердив домінування обмеженої групи країн за більшістю критеріїв. Побудова конкурентних карт глобального науково-освітнього простору за кількісними та якісними показниками розширює можливості ідентифікації диспозиції країн та відповідного вдосконалення стратегій взаємодії $з$ ними (Ільницький, 2016).

У своїй монографії Н. Чухрай, P. Патор, А. Лялюк "Маркетинг i логістика у вищому навчальному закладі" висвітлюють думку щодо карт-перцепцій. Вони вважають, що останні виконують два завдання: по-перше, підтверджують, який навчальний заклад сприймається в оточенні на фоні конкурентів у контексті вибраних критеріїв; по-друге, дозволяють ідентифікувати ринкові розриви (Чухрай, Патора \& Лялюк, 2008, c. 188).

Проаналізувавши зазначені вище роботи, можна стверджувати, що в розробці стратегій позиціонування закладів вищої освіти доречним буде застосування саме цих карт, що допоможе визначити прогресивність показників, котрі важливі для функці- онування та подальшого розвитку університету, а осі координат вказують на інтенсивність таких показників. У створенні або покращенні плану дій щодо результативності стратегій позиціонування навчального закладу посприяє саме аналіз отриманих даних за допомогою карт-перцепцій.

Для аналізу стратегій позиціонування провідних університетів Бельгії в міжнародному інформаційному просторі візьмемо до уваги індекс академічної репутації та кількість студентів. Отож розглянемо ефективність стратегій позиціонування ЗВО за двома показниками. За допомогою отриманих даних спробуємо зіставити, як споживачі освітніх послуг позиціонують університет та його конкурентів. Для цього розглянемо провідні університети Бельгії за наведеними вище параметрами у співвідношенні між собою (puc. 1).

Карта-перцепція складена для Левенського католицького університету, який займає перше місце з п'яти провідних університетів Бельгії. На другому місці Гентський, третьому - Лувенский

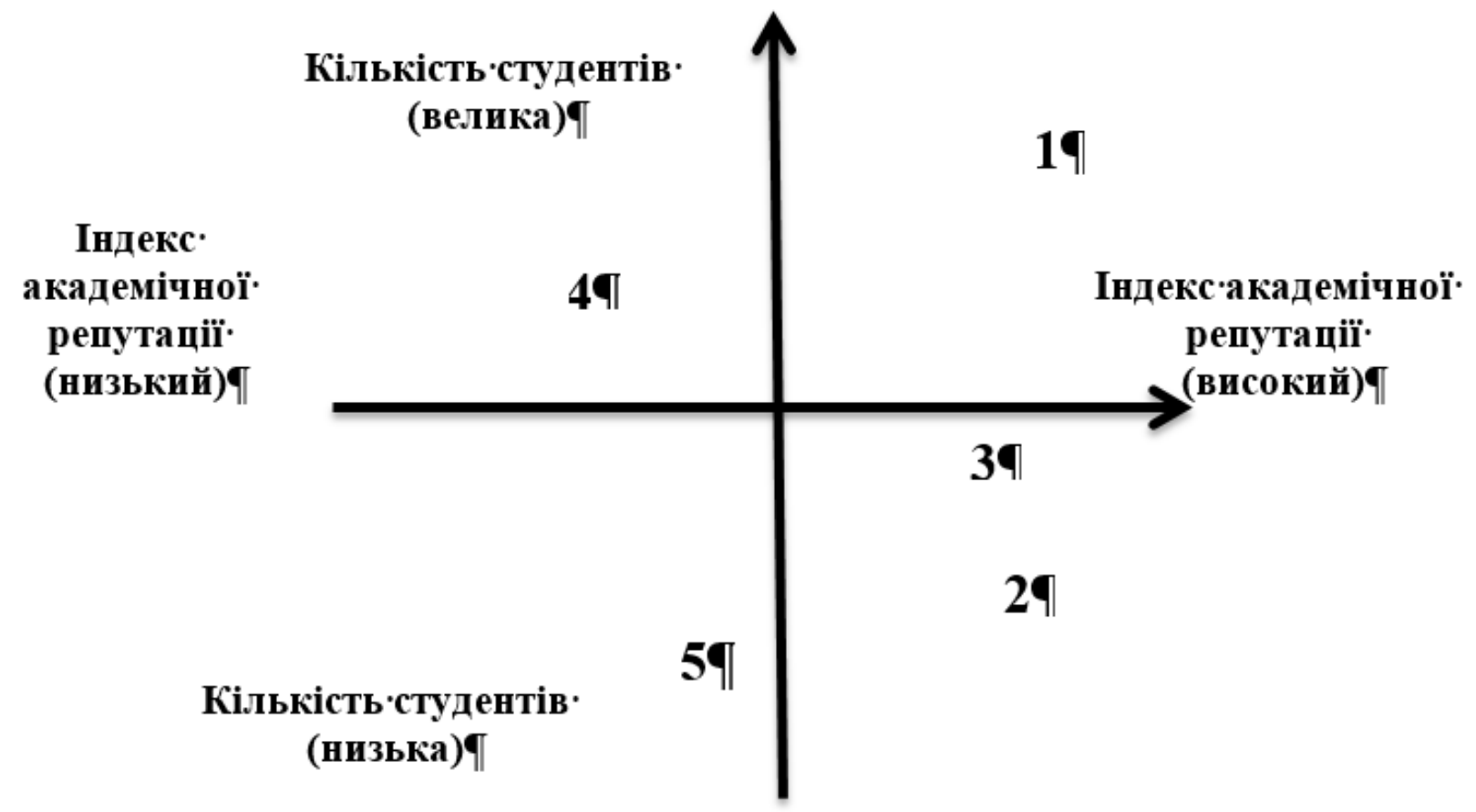

Примітка: 1. Левенський католицький університет. 2. Гентський університет. 3. Лувенский католицьки університет. 4. Брюссельський університет (ULB). 5. Вільний університет Брюсселя (VUB). 


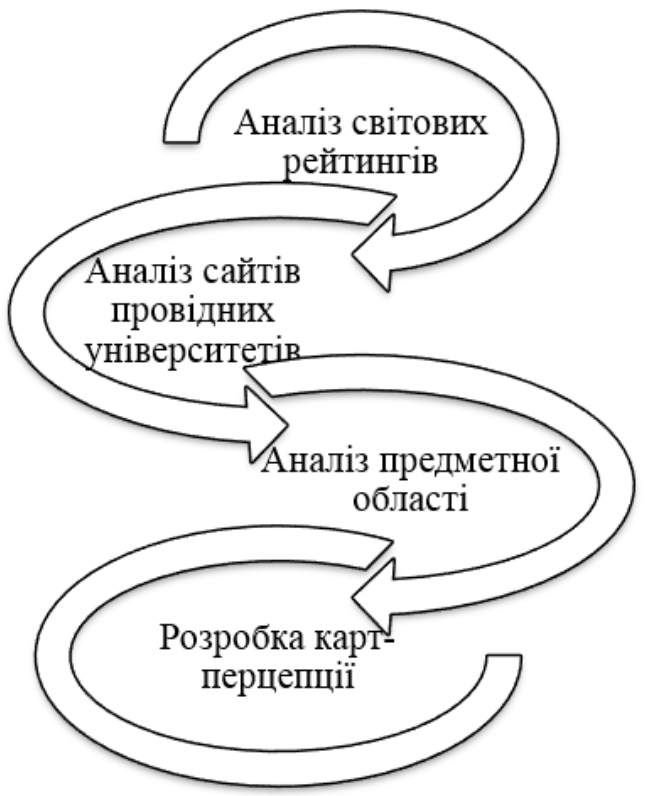

Рис. 2 Алгоритм методики аналізу стратегй позиціонування провідних універс итетів краӥн Свропи в МІП

католицький університет. На четвертому та п'ятому місцях Брюссельський вільний університет (ULB) i Брюссельський вільний університет (VUB) відповідно.

Розглянувши наведену карту, можна виявити недоліки та переваги інших конкурентних 3ВО. Так, Левенський католицький університет знаходиться у першому квадраті, тому що за світовим рейтингом університетів QS World University Rankings індекс академічної репутації становить 79,1, а також він має чималу кількість студентів - 46000.

У другому квадраті - Гентський університет, у якого індекс академічної репутації - 51,9, а чисельність студентів - 36185 осіб. Лувенский католицький університет має 51,3 індекс академічної репутації і 24444 студенти.

У третьому квадраті - Брюссельський університет (ULB) 3 такими показниками, як 33,8 та 26 708 , індекс академічної репутації та кількість студентів відповідно.

I в останньому, четвертому квадраті знаходиться Вільний університет Брюсселя (VUB), тому що у нього найнижчі показники академічної репутації, яка становить 25,9 , і найменше навчається студентів в університеті - 11227 осіб.
Отже, порівняльний аналіз дав змогу виявити відсутність ринкового розриву між досліджуваними провідними університетами Бельгії. Адже ми брали до уваги найпопулярніші університети, i, незважаючи на незначні розриви між ними, вони є найкращими у своїй країні.

Надалі в порівнянні стратегій позиціонування провідних університетів Бельгії в міжнародному інформаційному просторі (МІП), ми вважаємо за потрібне використовувати дані відповідно до галузі їх застосування, а саме: абітурієнти та студенти, науковці, викладачі, батьки, представники наглядової ради та адміністрація університету, професійні спілки, представники ЗМІ, працедавці, стратегії позиціонування освітніх і соціальних послуг, стратегії комунікації і ціноутворення.

Наприклад, Левенський католицький університет знаходиться на 80-му місці світового рейтингу QS 2020 року. I саме використавши дані, інформацію, яка знаходиться на сайті університету, та створивши карту-перцепцію щодо аналізу стратегій позиціонування в міжнародному інформаційному просторі, ми побачили, що цей $3 \mathrm{BO}$ орієнтований на всі групи споживачів і представлений за рахунок комплексу заходів з позиціонування, спрямо- ваних на розвиток напрямів, визначених у місії університету (свобода, різносторонність, творчість, строгість, відкритість).

Грунтуючись на порівняльнопедагогічних дослідженнях та їх специфічних особливостях, урахувавши наявну методику аналізу стратегій позиціонування організацій та підприємств відповідно до теми нашого наукового дослідження, нами розроблено методику проведення порівняльно-педагогічного аналізу стратегій позиціонування провідних університетів країн Свропи в МІП загалом (рuc. 2).

Методика аналізу стратегій позиціонування провідних університетів країн Свропи в МІП включає: аналіз світових рейтингів (для визначення провідних університетів конкретної країни); аналіз сайтів провідних університетів (для визначення додаткової інформації: кількість факультетів, особливості навчання, фінансування, стратегії розвитку тощо); аналіз "предметної галузі" стратегії позиціонування провідного університету в МІП (для отримання загальної картини діяльності університету щодо його позиціонування); розробку картперцепцій (щоб з'ясувати як ставляться студенти, абітурієнти та їх батьки до даного університету та його конкурентів).

Модернізація освіти в Україні в контексті входження до загальноєвропейського та світового освітнього просторів зумовлює потребу реального дослідження як ключових принципів освітніх реформ, так і можливостей їх реалізації (Харківська, 2009, с. 189192).

Необхідність адаптації українських ЗВО відповідно до європейських і світових вимог, а також урахування складних умов реформування економіки зумовили активізацію інтересу менеджменту до вироблення стратегій управління діяльністю закладами вищої освіти, оскільки без виявлення перспектив і прогнозування майбутніх тенденцій розвитку освіти практично неможливе i вироблення тактичних заходів іiі реалізації (Харківська, 2009, с. 47-54).

Висновки та перспективи 
подальших досліджень. Результати здійсненого аналізу дозволяють зробити висновок про те, що для отримання більш достовірної інформації про позиціонування університету потрібно порівнювати заклади вищої освіти не лише за одним показником, а за декількома, такими як: аналіз світових рейтингів, аналіз сайтів провідних університетів, аналіз предметної галузі, розробка карт-перцепції. I кожен цей показник важливий, адже є комплексним та різноплановим, таким, що дає можливість краще дізнатися про всі функції провідних університетів країн Свропи.

У процесі управління ЗВО стратегія позиціонування в МІП направлена на допомогу за такими напрямами: ідентифікація та репрезентація специфічних ознак закладу освіти/освітньої послуги/ освітнього продукту; реалізації місії, цілей, напрямів; аналіз оцінки споживачами освітніх послуг університету та його конкурентами; визначення сучасного стану позиціонування 3ВО та перспектив його розвитку; збереження i розширення досягнутих результатів.

\section{СПИСОК ЛІТЕРАТУРИ}

Ільницький, Д. О. (2016). Глобальна конкуренція в науково-освітньому просторі: інтелектуально-ресурсний вимір. (Дис. ... дpa економ. наук). Київський на- ціональний економічний університет імені Вадима Гетьмана, Київ.

Стоказ, Я. М. (2009). Формування стратегічних знань промислового підприємства. (Дис. ... канд. наук). Харківський національний економічний університет ім. С. Кузнеця, Харків.

Харківська, A. А. (2009). Аналіз варіативних систем профільного навчання в зарубіжному досвіді. Наукові записки. 1, 189-192.

Харківська, А. А. (2017). Стратегічне управління системою науково-методичної роботи ВНЗ. Проблеми інженерно-педагогічної освіти, 54-55, 47-54.

Чухрай, Н. I., Патора, Р. А., Лялюк, А. М. (2008). Маркетинг і логістика у вищому навчальному закладі. Луцьк : РВВ "Вежа" Волин. нац. ун-ту ім. Лесі Українки.

QS Top Universities. (2020). QS World University Rankings. Retrieved from https://cutt.ly/ ayTyY91.

\section{REFERENCES}

Iljnycjkyj, D. O. (2016). Ghlobaljna konkurencija v naukovoosvitnjomu prostori: intelektualjnoresursnyj vymir (Global competition in the scientific and educational space: the intellectualresource dimension). (Dys. ... dra ekonom. nauk). Kyivsjkyj nacionaljnyj ekonomichnyj universytet imeni Vadyma
Ghetjmana, Kyiv.

Stokaz, Ja. M. (2009). Formuvannja strateghichnykh znanj promyslovogho pidpryjemstvan (The formation of strategic knowledge of an industrial enterprise). (Dys. ... kand. nauk). Kharkivs. nac. ekonom. un-t im. S. Kuznecja, Kharkiv.

Kharkivsjka, A. A. (2009). Analiz variatyvnykh system profiljnogho navchannja v zarubizhnomu dosvidi (Analysis of variable systems of specialized education in foreign experience). Naukovi zapysky, 1, 189-192.

Kharkivsjka, A. A. (2017). Strateghichne upravlinnja systemoju naukovo-metodychnoji roboty VNZ (Strategic management of the system of scientific and methodological work of HEI). Problemy inzhenernopedaghoghichnoji osvity, 54-55, 47-54.

Chukhraj, N. I., Patora, R. A., Ljaljuk, A. M. (2008). Marketyngh i loghistyka u vyshhomu navchaljnomu zakladi (Strategic management of the system of scientific and methodological work of universities): monoghrafija. Lucjk : RVV "Vezha" Volyn. nac. un-tu im. Lesi Ukrajinky.

QS Top Universities. (2020). QS World University Rankings. Retrieved from https://cutt.ly/ ayTyY91.

Стаття надійшла 20.04.2020 p. 